\title{
TEOLOGIA NO DIVÃ
}

\author{
Theology on divan
}

\begin{abstract}
Osvaldo Luiz Ribeiro
Bacharel e mestre (Seminário Teológico Batista do Sul do Brasil - STBSB), Doutorando (PUCRio) em teologia (bíblica - AT), Professor de teologia e exegese do AT, e de hermenêutica e epistemologia na Faculdade Batista do Rio de Janeiro (STBSB), Rio de Janeiro, RJ - Brasil, email: osvaldo@ouviroevento.pro.br
\end{abstract}

Uma outra consequência decorre disso, para mim. A de acabar com o antigo ateísmo[...] Estou e continuo sem Deus, mas sei que não existe um ponto de vista depurado de todo mito ou crença, do qual se possa considerar com desprezo o mito e a crença. $O$ ateu deve descobrir sua crença - principalmente sua crença na razão -, seu fundamento irracionalizável, e relacionar-se com ela. Assim, nós, neo-ateus, podemos pedir aos crentes que se tornem neocrentes, isto é, que estabeleçam uma nova relação com deu(s) Deus(es).

(MORIN, 1986, p. 273)

\section{Resumo}

O ensaio analisa - e lamenta - a recepção negativa do século XIX (Kant, Schopenhauer, Feuerbach, Nietzsche, Marx, Freud, Dilthey) pela teologia, porque considera que a atual fase da cultura ocidental tem ali assentado um de seus alicerces, de modo que, negligenciando-os, anatematizando-os, tendo-os por inimigos, a teologia descola-se da plataforma epistemológica em voga, constituindo-se, por conseguinte, em discurso anacrônico (medieval), "neurótico" (subjetivismo míticovoluntarioso fechado) e incompatível (descolamento científicohumanística). O autor postula uma conversão honesta da teologia não 
apenas aos valores das Ciências Humanas, filhas daquele século, mas sem negociações - inclusive à sua cosmovisão, consequentemente, compreendendo-se a si mesma como mito (os conteúdos milenares da teologia) e método (o que lhe cumpre ser, agora e então).

Palavras-chave: Teologia; Romantismo; Epistemologia; Metafísica; Compatibilidade.

\begin{abstract}
The essay analyzes - and regrets - the negative reception of the nineteenth century (Kant, Schopenhauer, Feuerbach, Nietzsche, Marx, Freud, Dilthey) by theology, because it believes that the current phase of western culture has one of its foundations settler there, so that neglecting them, anathematizing them, taking them by enemies, the theology is off the epistemological platform in vogue, constituting itself into, therefore, in speech anachronistic (medieval), "neurotic" (closed mythical-obstinate subjectivism) and incompatible (scientific-humanistic detachment). The author posits an honest conversion of theology not only to the values of Human Sciences, daughters of that century, but - without negotiations - including its worldview, therefore, it being understood itself as myth (the millenary contents of the theology) and method (what it has to be, now and then).
\end{abstract}

Keywords: Theology; Romanticism; Epistemology; Metaphysics; Compatibility. 


\section{Introdução}

O meu propósito imediato é, como "insider", compartilhar minha análise epistemológica da teologia, de modo geral, e da contemporânea, em particular. A teologia acha-se no direito de frequentar as cátedras das Ciências Humanas, como uma delas, mas - eis meu juízo - recusa-se a passar pelo século XIX, apresentando-se, mesmo quando se diz pública, como "saber", e, em ultima análise, "saber" revelado. Em suas três frentes de combate - Vaticano, Barth, The Fundamentals - soterrou o século XIX, desconsiderou epistemologicamente a seriedade do postulado históricoepistemológico do Romantismo - a "consciência histórica" -, e reinaugurou a Cidade de Deus. Minha crítica esboça-se no sentido de apontar para a absoluta falta de fundamentação científico-humanística dos "conteúdos" tradicionais da teologia, e isso justamente porque ela se recusa a uma conversão científico-humanística, sem a qual, contudo, ela não tem - nenhum - direito de cátedra no concerto das "ciências".

Sempre sob meu juízo, a teologia nasceu estética, tornou-se política, mas recusa-se a adequar-se à heurística. Nos termos da sociedade republicana, sob o regime do Estado Democrático de Direito, o firmamentum mítico da "criação" é levado epistemologicamente a sério, e os discursos, humanos, demasiadamente humanos, emergem programaticamente a partir de consensos epistemológicos romântico-empírico-científico-humanísticos, e, sob a condicionante de compatibilidade, não podem condescender com registros discursivos carregados de pretensão místico-metafísico-ontológica. Uma teologia que cuida "saber" de "Deus" precisa, urgentemente, de terapia.

O jogo medieval acabou. Bom. Bem - que pena - não, ainda, para a teologia. 


\section{O descolamento epistemológico do século XIX - neurose ${ }^{1}$ e self deception}

O século XIX não existiu para a teologia. Infelizmente, não é força de expressão. É a constatação, pura e simples - o século XVIII terminou e, no calendário eclesiástico, o calendário saltou para o século XX. Quem estava lá, jura ter ouvido um "ufa!". Eu não estava, mas acredito piamente no testemunho. Por quê? Porque a teologia do século XX, simplesmente, desconsidera tudo quanto de fundamental lhe foi dito, ao pé do ouvido e/ou desde sobre os telhados, no século XIX. E não é que a teologia seja propriamente surda. A teologia tem excelentes ouvidos - ela ouve anjos! O que ela não ouve é a sim mesma, ela padece de "birra auditiva" - e nós sabemos: quando não se quer ouvir, não se ouve. Os fatos são amigos, mas a teologia não consegue parar e enfrentar definitivamente o século XIX - ela foge dele, como o diabo da cruz.

Seria muito bom se a teologia levasse a sério o primeiro Kant - o da Crítica da Razão Pura. Mas ela fez acordos subterrâneos com o segundo, o da Crítica da Razão Prática - e, aí, a ética ontológica do imperativo categórico saltou no meio da sala: "quem me vê, vê Deus" - "quem me sente, sente Deus" (BERGER, 1985, p. 165-180). A teologia, nesse ato, é o contra funâmbulo de

\footnotetext{
Para fazer-me o mais claro possível, ensaio uma definição "situada" do que - aqui - chamo de "neurose": o estado psicológico da teologia, quando ela insiste em viver "em seu próprio mundo", metafísico-ontológico, engendrado por ela mesma - o que seria obviamente hígido, não fosse sua decisão histórico-existencial de descolar-se da plataforma cultural ocidental (= a epistemologia científico-humanista e político-filosófica da cultura emancipada, emergindo desde o século XIX sobre o Ocidente). Assim, o mundo da teologia resulta relativamente anacrônico e defasado em relação ao referencial epistemológico chave (em regime metafórico arquitetônico, "fundamental") da sociedade civilizada ocidental contemporânea. Essa neurose responde unilateralmente a um "princípio de prazer", em detrimento da necessidade de considerar o "princípio de realidade". Essa "neurose" é, ainda, ameaçadora, porque ela se traduz não apenas na decisão do/a teólogo/a de viver em seu mundo, mas de arrastar para dentro dele tudo e todos. Deixo registrado, portanto, que, aqui, o conceito de neurose não é aplicado nos termos em que Freudo aplicava à religião - "thus religion, according to Freud, is a repetition of the experience of the child " (FROMM, Erich. Psychoanalysis and relgion. London: Yale University Press, 1971. p. 11). Para uma abordagem da religião como neurose em Freud, RICOEUR, Paul. Freud and philosophy: na essay on interpretation. London: Yale University Press, 1970. p. 253. KÜNG, Hans. Freud and the problem of God: enlarged. London: Yale University Press, 1990. p. 109.
} 
Zaratustra (NIETZSCHE, 1989, p. 6-7). A teologia perdeu, uma grande oportunidade de reconhecer seu berço e sua fase de mito, e inaugurar sua fase de conhecimento, de bom-senso, fase que revelar-lhe-ia, decerto, sua incontornável mitoplastia eidética, pseudo-filosófica, cripto-mitológica, e, de posse de cujo diagnóstico, assumir-se-ia, então, como tal - mito -, e gritaria, ela mesma, antes que um Onfray (2007, p. 29-50) ${ }^{2}$ escrevesse algo tão pobre e rasteiro, notório e frágil: "Ei, vocês aí, eu confesso, eu sou, eu sou - mito!". A teologia aceitou a metodologia histórico-crítica - até o Vaticano! -, mas olhar no espelho, e ver-se mito, não, não tão fundo. Ah, que pena.

A rigor, é do Romantismo que a teologia tem horror - horror ao vazio, horror ao firmamentum intransponível. Poder olhar bilhões de anos no cosmos, mas nem um milésimo de segundo fora dele! A teologia quer, precisa, olhar para fora do cosmos, para além do Universo, para o mais longe possível de si mesma, para, aí, não ter que olhar-se a si mesma, e ouvir-se a si mesma. Depois de ter trazido o não-tempo para a Física (PRIGOGINE, 1996, 2002), ela ainda quer olhar o não-tempo do Ser que ela concebeu (FEUERBACH, 1988).

Não é propriamente do Iluminismo que a teologia tem medo. Que the pode fazer a "razão"? Ora, a Razão - "deusa" e "diaba" - pode até lhe servir de rival - mas e daí? Ontem ainda, não nos alertava José Saramago (1991, p. 363 400) para o fato de que Deus quer o diabo sempre perto de si? Pois então - que ruja a Razão, que Yahweh foi especialista - outrora, mas sempre se recupera o manejo da lança - na prisca arte de matar Yam. A razão, quando instrumentalizada na peleja contra a teologia, perde, porque a teologia - ou a razão, quem o quiser que decida - faz o papel daquele trapaceiro de que nos alertava, anteontem, Johan Huizinga (2005, p. 14-15). A teologia tem medo, mesmo, é do Romantismo, porque, aí, sai de cena o trapaceiro, e entra em cena o desmancha-prazeres, o que não quer mais jogar, porque o jogo, ele viu, ele diz - esse é o problema! - não funciona, é sem-graça. Ainda que viciados, o que importa à teologia é que rolem os dados.

Daí que, Cérbero rugindo, a teologia evocou seus campeões. Roma organizou o Vaticano I, e foi lá que se ouviu um primeiro "ufa!". Nada mais importa - seja o chão duro como diamante, ou diáfano como o nada, teologia é

Li com ansiedade e sofreguidão o Tratado de Ateologia. Esperava encontrar, ali, ensaios de uma crítica epistemologicamente profunda. Mas frustrei-me. Minha crítica pode ser lida em minha página de trabalho:<http://www.ouviroevento.pro.br/diversos/resenha_de_Onfray.htm>. 
teologia, porque tem fundamento infalível. O jogo continua. Em "Wittenberg" - a capela! -, um novo Lutero, Karl Barth, faz crer a todos os que tem olhos de ver e ouvidos de ouvir que, com ou sem Romantismo, com ou sem céu de chumbo, Deus fala, e a teologia - jamais a natural!, só a revelada! - ouve, entende e traduz. Aí também se ouviu um "ufa!". Cá do outro lado do Atlântico, The Fundamentals eram escritos com a mesma estratégia de fundo - garantir, a todos que de garantia precisam, que a fé está muito bem e o inferno, vai-se enchendo. E, como os serafins - ufa!, ufa!, ufa! E - assim - nos três salões da teologia, o século XIX foi apagado da lousa, fechado no efa, e levado para Babilônia.

Não é que tenha sido pela primeira vez na história que se tenham dito as coisas que se disseram no século XIX. O ceticismo tem mais de dois mil anos! E, no entanto, pela primeira vez, o "mundo" estava pronto para "ouvir". Mil anos de preparo, em banho-maria, fogo lento, mas eficiente. Inexorável. Os árabes na Europa. Aristóteles no embornal. A Renascença - renascimento! A imprensa. A Reforma. O liberalismo político-filosófico inglês. O empirismo inglês. A "revolução" estadunidense. As Luzes. A Revolução Francesa. As Repúblicas. O Romantismo. As "Ciências Humanas" - a invenção do conhecimento. Essa extraordinária massa, fermentando, vazou para fora da fôrma que os Cristianismos revelados, juntos, haviam forjado - e eram, todos eles, homens de Igreja(s)! Ironia. O século XIX é o século que recebe as águas daquele dilúvio em gestação. Águas violentas, águas de pororoca, águas de tsunami - águas do último março de uma era. O primeiro Kant (2001), Schopenhauer (1963, 2001), Feuerbach (1988), Marx (1992), Nietzsche (1988), Freud (2006), Dilthey (1991) - vomitaram tudo e de uma vez, e tão alto, e tão fundo, que a teologia assustouse, amedrontou-se, apavorou-se. E reagiu sua reação de província, de corporação, de tapar os olhos, de tapar os ouvidos - mas não, a boca.

De Kant recolhemos a constatação inapelável - fé não é saber, nenhuma fé, de pobre ou de rico, de grande ou de pequeno, do norte ou do sul, e, quanto ao que pode ser sabido, quando muito o inextricavelmente histórico, intra-humano, prostático, uterino, e, ainda assim, de uma humaníssima maneira. Céus de chumbo. De Schopenhauer, avançamos para a compreensão do mundo como representação (que PEIRCE, 2003, formulará de modo rigoroso e preciso, quando propuser, daqui a pouco, a semiótica) - e vontade. Feuerbach - que dívida! - a revelar - a que preço! - a consistência mítico-hipostática do sonho ocidental, e desvendar o segredo da teologia - antropologia. Um Feuerbach que Marx criticará, porque insatisfeito com o recorte essencialista-idealista da crítica, convencido dela, contudo. É que 
o seu diagnóstico é material e dá contas da alienação humana, espécie histórica a expressar-se fora de si, fora de seu centro de gravidade, corpos não-nascidos ainda - e, logo, abortos antropológicos, que, a seu tempo, Nietzsche reduzirá ao conceito de "rês", longos os lombos e muita a carga. ${ }^{3}$ Se Feuerbach foi sutil e letal, Nietzsche foi letal e ostensivo, e soube, por primeiro, que "Deus" estava morto. Fora um mal-estar, uma neurose coletiva, dirá, à tardinha, Freud. Finalmente, fechando e corrigindo o ciclo aberto por Kant, Dilthey encerra-nos, homens e mulheres, na "vida" e na "história"4 - sem sursis.

Ora, o que há nos anúncios desses cavalheiros românticos de tão grave? Deviam ser louvados, e consagrados em festas cosmogônicas de Anos Novos. Tudo quanto falaram - a respeito do que aqui tratamos - é - assim julgo - de extrema lucidez e bom-senso, tem o cheiro de nosso tempo, a cor da nossa terra. Que não se pode nada saber sobre o que é supra-(e infra)humano. "Saber". Inventar, criar, imaginar - sim. E isso que se inventa, cria e imagina torna-se tão vivo e real quanto nós, inventores-criadores-imaginadores (MORIN, 2002, p. 131-138) - elas nos comem vivos, enquanto as inventamos, as idéias! Mas o "além" - nem quando, por prestidigitação retórico-homilética, transformado em além-aqui-revelado pode ser "conhecido", "sabido", não na "invenção" de saber da sociedade emancipada, humanístico-científica, que inventamos há dois séculos. Barth, Barth, que atraso nos causaste! Cem anos perdidos.

"O animal doméstico, a rês gregária, a enferma besta humana - o cristão". As expressões referem-se à descrição que Nietzsche faz da "espécie de homem" que o "Cristianismo" inventou, submetido, sempre, a terceiras consciências como que à sua mesma. Daí, "rês". Antes, ele dissera que "o problema que aqui coloco não é qual a sucessão do homem na escala dos seres (- o homem é uma finalidade - ?) mas sim qual o tipo de homem que se deve criar, que se deve pretender" (NIETZSCHE, Friedrich. W. O anticristo: ensaio de uma crítica do cristianismo. Lisboa: Guimarães, 1988, p. 15-16).

4 "Dilthey contra Kant: seu sujeito é muito abstrato, sem carne e sangue. Não se pode ir além do sujeito, é verdade. Mas que sujeito? Para Dilthey, é a vida, a história. Um sujeito histórico com uma 'experiência interna' não exclusivamente racional. Um sujeito com vontades, com paixões, intencionalidades, afecções, 'um feixe de pulsões', que constrói sua vida criando e seguindo valores particulares. Contra a razão pura, Dilthey propõe uma filosofia da vida. Não se pode ir além da vida. Ele pensa que, por isso, só ele teria de fato superado a metafísica. Para ele, a vida era ao mesmo tempo psicológica e histórica, e não 'pura', abstrata, racional, sistemática e muito menos transcendente. Contra a crítica da razão, que ele considera ainda metafísica, propõe uma crítica da razão histórica ou uma crítica histórica da razão pura" (REIS, José Carlos. Dilthey e o historicismo: a redescoberta da história. In: REIS, José Carlos. História e teoria: historicismo, modernidade, temporalidade e verdade. Rio de Janeiro: FGV, 2003. p. 235). 
Por que desprezar Nietzsche? A teologia não percebe que quanto mais esforça-se por contestar o "louco", tanto mais afunda em seu próprio atoleiro, a "criatura" carregando o corpo morto do "criador"? Não se vê que inventamos uma máquina política - a República, expressa na forma do Estado Democrático de Direito -, que é metodologicamente cética - deve/deveria ser - e laica - deve/ deveria ser -, e que funciona sem Deus, conquanto homens e mulheres, republicanos que sejamos, ainda operam no regime do mito, alienados da consciência de mito? Ah, O Anticristo - mil vezes mais relevante do que A Cidade de Deus. Mas a moral da pirraça, da vingança de criança mimada, a birra imatura, os "olhos de fariseus" - ah, não queremos ler isso. Que pena. Praticamente irretocável.

Sim, é verdade que Marx e Freud mostraram apenas um lado da moeda - ópio e neurose. Sim, é verdade que a religião, a teologia, não é apenas ópio e neurose. Mas o são também. E a cada gesto da teologia de recalcar sua condição neurótica, tanto mais ela assim se ostenta. A praça toda vê, e balança a cabeça. A patologia - diagnóstico possível "apenas" à luz do "mundo" que inventamos não é a fé, a crença, a imaginação lúdico-mítica, o sonho, o delírio, o desejo, a "saudade", a fratura, a ruptura, a falta, o vazio. Isso tudo é muito humano, constitutivamnte humano. Muito bom, inclusive. Sadio. Saudável. A patologia é a paciente - compreenda-se o regime da metáfora - "cismar" que se trata, isso tudo, de "saber". Não, nada disso é "saber", nada disso é "conhecimento". Tudo quanto a teologia produziu de conteúdo desde que o Monge da Caverna escreveu pela primeira vez o seu avatar no pergaminho é "mito" e "crença". Não reconhecer isso, não sei se concordas comigo, é a maior neurose da teologia contemporânea. A teologia tem um "amigo imaginário". E isso é o que ela não quer sabe(r).

A teologia do século XX - ainda não encontrei legítimas exceções nunca leu Zaratustra, nunca atravessou o século XIX, e ainda vive na Cidade de Deus. O que - juízo meu - é de todo lamentável. Abrimos o século com um homem infalível em Roma, com um ouvido hierológico nas Alemanhas e com as "Tábuas do Sinai", na "América". Fico com a neurose protestante. Bultmann quer crer a qualquer custo. Diz apagar toda a mitologia e nega toda a "revelação natural" (vício - sintoma? - protestante). Mas abrem-se as portas seculares de madeira, rangendo sob o peso da impaciência da história, e lá vem ele com um querigma (BULTMANN, 1987, p. 13-45), que nada mais é do que a mais sutil forma de mito racionalizado. Mito que um pregador evangélico-protestante com um milésimo da formação exegética dele prega durante uma viagem do trem. 
Do outro lado do Mar, Tillich - e é, por muitos, considerado o maior de todos - trava sua luta "com e contra" - ele confessou - a secularização. Assim como - juízo meu - Aquino castrou Aristóteles, Tillich quer amansar o tigre quem sabe, trazê-lo para a Cidade de Deus, para a Religião do Espírito Concreto (TILLICH, 1977, p. 108; RIBEIRO, 2007). Seu último desafio pessoal era corrigir seu "equívoco" - ele confessa - histórico: ampliar seu provincialismo teológico para abarcar, agora, também a História das Religiões. Insisto - não se tratava, com Tillich, de romper com a percepção ontológico-metafísica da "verdade" revelada, mas de trazer para dentro dela a expressão cultural da sociedade moderna. Em última análise e à semelhança de Bultmann, apenas uma nova linguagem. A meu ver, nada mais que isso.

Mais próximos de nós, mortais, pronunciamentos ainda marcados pela perspectiva pré-humanístico-científica, mitigados, é verdade, muito mais pelo constrangimento da "academia", do que por razões epistemológicas - fossem epistemológicas elas, não se ouviriam eles. Faustino Teixeira defende o lugar da teologia na(s) Ciência(s) da Religião, apresentando-a como "inteligência da fé", "reflexão 'à luz da fé"”, "sempre (d) o ponto de vista humano" [princípio científicohumanístico de mitigação do zelo crente]. Cabe-lhe estar metodologicamente "atenta" "à irrupção de Deus na história e aos sinais históricos dessa presença" (TEIXEIRA, 2001, p. 301, 310). Em sua nova face "vaticana", ela quer refletir sobre o "significado do pluralismo religioso no plano de Deus" - percebes? -, bem como " "sobre o significado e o valor das tradições religiosas mundiais à luz da revelação cristã"” (TEIXEIRA, 2001, p. 314). Ela, essa teologia, é "crítica", diz Faustino Teixeira, com o que ele assinala o seu caráter de "reflexão que se mantém vinculada aos imprescindíveis laços da fé e da revelação, mas que guarda sua autonomia e liberdade face a qualquer autoridade" (TEIXEIRA, 2001, p. 309). Honestamente, não penso que "essa" teologia tenha lugar à mesa com as Ciências da ou das Religiões. Nenhum assento, porque estas são invenções do século XIX, são burras demais para as questões metafísicas, lobotomizadas, para poderem sequer iniciar diálogo com um conjunto de proposições de fé, assumidas como reveladas, e consideradas? - "imprescindíveis". Essa teologia não tem nenhum direito de estar onde logrou estar. Ela é puro mito. Se sabe disso, não tem o direito de argumentar no registro retórico em que se apresentou. Se não sabe, mais uma vez, negligenciou o século XIX. E eu, confesso, acredita-me, pego-me com medo de estar refletindo sob inexoráveis equívocos, porque não é possível que me pareça tão cristalina essa condição "medieval" da teologia - estarei eu epistemologicamente equivocado? 
Por sua vez, a EST lançou, recentemente, um volume de sua revista Estudos Teológicos -, onde, dentre outros temas, discute-se, em três artigos, o "estatuto" da teologia. ${ }^{5}$ Para von Sinner, a teologia ainda lida - e metodologicamente -com o falar de Deus. Para Zabatiero, a teologia é pósmetafísica, mas ainda é "saber racional público". Zabatiero assume acompanhar a estratégia de Gianni Vattimo e Richard Rorty, e, assim, se estamos atentos ao "pragmatismo" rortyano e à "hermenêutica" vattimoniana, alertamo-nos para o fato de que "saber", aí, traduz-se em "linguagem" - apenas. Por sua vez, o projeto de pesquisa de Mueller parece ter potencial para encaminhar-se para uma discussão mais epistemologicamente assentada, se, contudo, a estratégia de fazer da teologia uma rotina de "interpretação da realidade à luz da esperança" eventualmente não dissimule, a médio e longo prazo, a manutenção tácita dos conteúdos teológicos como referencial da esperança. Devem cair todos os axiomas da teologia medieval, metafísica, para que possa surgir sua sucessora e herdeira. Não é apenas o "lugar" da teologia que está em jogo, sua utilidade é ela mesma, inteira, cada proposição, cada conteúdo, nada dela está livre do sobreviveu ao - dilúvio romântico. É preciso sentir o terremoto até os ossos - e, se não há terremoto, não se passou pelo século XIX.

Num ponto comum, os três teólogos estão corretos - é urgente a necessidade de discussão séria sobre o estatuto epistemológico da teologia - e discussão séria significa discussão sob o regime das “ciências", e não, jamais, uma racionalização apologética elaborada pela própria teologia. Ontem, ainda, a teologia recebeu carteirinha do MEC. Não espere para ler as atas das discussões epistemológicas do concerto das Humanidades, pois não houve "consulta pública". Nossos, agora colegas, antropólogos, epistemólogos, sociólogos, filósofos, biólogos, físicos, o povo das letras, das línguas, quer dizer, esse povo enorme com quem,

Refiro-me, aqui, ao v. 47, n. 2, de 2007, especificamente a três artigos que procuram apresentar reflexões sobre o estatuto epistemológico da teologia, a saber: von Sinner, Rudolf, Teologia como ciência. Revista Estudos Teológicos, São Leopoldo, v. 47, n. 2, p. 57-66, 2007 ("teologia como a reflexão metodologicamente responsável sobre o falar de Deus"), Zabatiero, Júlio Paulo Tavares, Do Estatuto Acadêmico da Teologia: pistas para a solução de um problema complexo. Revista Estudos Teológicos, São Leopoldo, v. 47, n. 2, p. 67-87, 2007.(“teologia como um saber racional público e não como um saber científico"), e Mueller, Enio R. A teologia e seu estatuto teórico: contribuições para uma discussão atual na universidade brasileira. Revista Estudos Teológicos, São Leopoldo, v. 47, n. 2, p. 88-103, 2007. (“teologia como interpretação da realidade à luz da esperança"). 
agora, cruzamos pelos corredores, que cumprimentamos, não, eles não "opinaram" sobre nosso ingresso. ${ }^{6}$ Mas entramos. Foi sempre assim que fizemos - entramos na casa das pessoas, nas cidades delas, na vida delas, sofremos de uma síndrome de megalomania noológico-metafísica. ${ }^{7}$ E cá estamos. Teologia no MEC.

Mais do que isso - quer-se, agora, dar o título de teólogo a qualquer representante de religião que tenha serviços religiosos prestados por cinco anos, independentemente de ter "estudado teologia". ${ }^{8} \mathrm{Ah}$, é aqui que as coisas vão ficar boas. Lamentavelmente, esse imbróglio não vai ser resolvido epistemologicamente, mas seria interessante ver-nos, teólogos, engalfinhandonos, uns a defender que "teólogo" tem que estudar - "no plano de Deus", naturalmente - e outros a defender que "teólogo" é carisma. Mas, vejo aí apenas tristeza e lástima, porque são as mesmas forças que nos colocaram "aqui" que agora ensaiam operar novas "conquistas".

6 E deveriam. O ingresso da teologia representa um acréscimo de pressupostos ao conjunto das abordagens científicas. O conceito, já em declínio, de "interdisciplinaridade" e seu sucessor, o de "transdisciplinaridade", impõem que as disciplinas interpenetrem-se mutuamente. Nesse ponto, o ingresso da teologia sem o consentimento dos demais "jogadores" gera um desequilíbrio no sistema, bem como um constrangimento político. Que papel o "saber" (?) teológico pode assumir na Universidade? Se ela não se faz pesquisa histórica, se ela não se transforma em reflexão filosófica, nenhuma. E, contudo, cá estamos nós.

7 O "fizemos" é programaticamente inclusivo. A teologia sofre do mal de Parmênides - não apenas seu Deus é o Ser, mas a reflexão, a atitude e a prática teológica tendem a subsumir-se ao conceito. Nesse sentido, o compromisso tácito com o "jogo" teológico metafísico torna relativa a questão de se quem "invade" a casa das pessoas são os/as teólogos/as ou os/as missionários/as, assim como é irrelevante a discussão sobre a imputação de responsabilidade a A ou a B pela "culpa" dos crimes da Igreja na história. Chega um momento em que, em última análise, a "culpa" é ampla, geral e irrestrita. A solidariedade com o "valor" da fé torna-nos, consequentemente, solidários com seu "vício". Mesmo quando combatemos o "pecado" do Cristianismo, ainda aí há sangue em nossas mãos, e peso sobre nossos ombros. Nas minhas mãos, sobre meus ombros.

8 Refiro-me aos Projetos de Lei do senador Marcelo Crivella (PRB/RJ) e do ex-deputado Victorio Galli (PMDB/MT), que postulam a concessão do título de "teólogo" a não-diplomados que há mais de cinco anos exerçam efetivamente a "atividade de teólogo", uma vez que, segundo o postulado em que se baseiam, "teólogo é o profissional que realiza liturgias, celebrações, cultos e ritos; dirige e administra comunidades; forma pessoas segundo preceitos religiosos das diferentes tradições; orienta pessoas; realiza ação social na comunidade; pesquisa a doutrina religiosa; transmite ensinamentos religiosos, prática vida contemplativa e meditativa e preserva a tradição " ("Projetos dão título de teólogo a religiosos sem formação ", notícia acessada em 10/05/2008, em http://www.estadao.com.br/geral/not_ger142115,0.htm). 


\section{Por uma conversão da teologia ao século XIX - terapia contra recalque e incompatibilidade}

Nós inventamos o século XX, depois de chocar o XIX. Justamente aí, inventamos a "escola" moderna - toda ela, todinha, humanísticocientífica. Durou cem anos. A UNESCO, agora, quer inventar uma nova escola. Morin propôs Os Sete Saberes Necessários à Educação do Futuro (MORIN, 2004, p. 19-33). Marca inaugural do sistema - "incerteza" e consciência metodológica do risco de self deception. A teologia tem de ler isso. Mais - tem de ler O Método inteiro, os seis volumes. Descobrirá ali que o "deus morto" de Nietzsche transformou-se em "ser de espírito", "ser noológico", habitando a noosfera - que criamos e mantemos à custa de nossas energias mitocondriais. Lucidez. No mito, somos criaturas. Quando abrimos os olhos, somos criadores. A teologia quer confessar isso? Confessar que está pronta para o século XXI? Ou - é direito dela - prefere reconstruir o medievo, quem sabe, jantar com Justino, Ireneu e Tertuliano, para anatematizar os Cavaleiros do Apocalipse dos mil e oitocentos?

Haveria vantagem em a teologia admitir-se como mito, e a seus conteúdos de "fé" - todos" - como mitos? Bem, as vantagens são relativas, é claro. Primeiro, é inadmissível que eu "creia" e diga que "sei" - ah, sim, o problema da teologia nem sempre é subjetivo: na maior parte das vezes é eclesiástico e sistêmico. É indecente que eu "creia" e diga que "sei". Concordo com Huxley - manipulação de massa, ainda que "para o bem", não se justifica moralmente (HUXLEY, 1992, p. 327-328).

Segundo, porque a palavra de ordem para o concerto das ciências é "compatibilidade" (DOSSE, 2003, p. 265) - e não há a mínima possibilidade de "acordo" entre um conhecimento arrancado/construído e um fideísmo voluntarista racionalizado - e não se trata apenas do conteúdo tradicional dos Cristianismos, mas de todo e qualquer sistema de "crenças" mítico-metafísicas, ontológicas e dedutivas. Há, hoje, muito espaço para a expressão religiosa (BERGER, 1985). Mas, ela deve - necessariamente, civilizar-se, republicanizar-se, científico-humanizar-se, "esclarecer-se/desalienar-se". A partir daí interessar-se-á ela mesma pelo estatuto epistemológico de sua pragmática. Os únicos conhecimentos possíveis na "teologia" são aqueles obtidos (descobertos/construídos) quando, cristalizada na história - na forma de cânones, de dogmas, de decisões, de atos, de gestos, de retóricas, de êxtases 
- ela é venatório-indiciariamente (GINZBURG, 2007, p. 143-179), filologicamente ("o ler bem" - NIETZSCHE, 1988, p. 105), ${ }^{9}$ investigada. O bom teólogo, a boa teóloga - para o dizer em conformidade com Hans Küng (1999, p. 196 - "teologia histórico-crítica!) ${ }^{10}$ e o Vaticano (PONTIFÍCIA COMISSÃO BÍBLICA, 2002, p. 37, 124-138) -, são Sherlock Holmes (GINZBURG, 2007, p. 145). Um terceiro olho, à semelhança do que ganhou Lobsang Terça-Feira Rampa, não serve mais para nós. Nem um ouvido (cripto)metafísico. Não, pelo menos, no "jogo" das "Ciências".

Terceiro, como Edgar Morin (2003, p. 295) não cansa de repetir, "chegamos em casa" - o Planeta. Aquela primeira diáspora africana, essa metástase antroposférica, sociosférica, atingiu um ponto-crítico. Tornamosnos estranhos, nós que, um dia, começamos a Jornada. Acotovelamo-nos, agora, num planeta-incógnita. Um deus?, nenhum?, dez mil? Não completamos o ciclo noológico. É preciso fazê-lo. E, para tanto, é necessário que a teologia converta-se a Terra, e reconheça-se filha daqui, dela. É preciso que a teologia nos deixe sozinhos - e é possível, sim, uma teologia ciente e ciosa da condição noológica (iniludível e ineludivelmente noológica) de sua(s) divindade(s), seus anjos e demônios, seus santos e diabos. É preciso que a teologia nos deixe aprender a construir sozinhos (porque somos nós quem temos de construir!) nossa casa e vida planetárias. Tentam-se acordos "religiosos" por meio de "diálogos" - mas, ouso advertir, nenhum projeto que se desvie da discussão incontornável da condição epistemológica da "religião" logrará êxito. Paz, pela paz, o Estado Democrático de Direito, a seu tempo e modo, a promove. Mas, deixou-nos sentados nas calçadas, que resolvamos nós mesmos nossas diferenças. E - no fundo - não as há, porque somos todos sonhadores hipnotizados pelo sonho. É preciso acordar. E saber que é sonho o sonho que se sonha - como se sonho não fora.

Não vou, aqui, esboçar um projeto de teologia pós-metafísica. Meu objetivo é tão somente pontuar que a teologia, no divã, precisa de terapia. De terapia, porque, cem anos depois da pirraça de Barth, do desespero teológico

9 "Outro sinal distintivo dos teólogos é a sua incapacidade filológica. Eu entendo aqui por filologia, em sentido geral, a arte de ler bem, de saber distinguir os fatos, sem os falsear com interpretações, sem perder, no desejo de compreender, a precaução, a paciência e a delicadeza".

10 "Precisa-se de uma teologia feita a partir do atual horizonte de experiência, uma teologia rigorosamente científica e, portanto, aberta ao mundo e orientada ao presente. Parece-me que só essa teologia merece hoje um lugar na universidade, ao lado das outras ciências"

Rev. Pistis Prax., Teol. Pastor., Curitiba, v. 1, n. 1, p. 199-218, jan./jun. 2009 
diante das sombras que cobriam - e para sempre - o planeta, depois de Freud, de Lacan, de Jung, de Rogers, de Reich, ela ainda tem pesadelos, ainda ouve vozes, ainda tem visões. Nem todos os banhos frios lhe renderam sanidade psicológica. É preciso, pois, que a teologia procure um analista, e que fale pelos cotovelos, vomite suas prédicas homiléticas, isso tudo para ver se o analista ajuda-a a encontrar-se consigo mesma. Um analista como o Morente, quem sabe, que, inicialmente, lhe diria que, cripto-filósofa (Platão era filósofo ou teólogo?), ela se "infantilize", isto é, volte a ver o mundo como criança, com a surpresa curiosa dos meninos e das meninas a levantar pedras e ver o que há embaixo (MORENTE, 1980, p. 35-37). ${ }^{11}$ É preciso desconstruir-se, para voltar, depois de adulto, a ser criança. Dói, às vezes. Por isso, é ela mesma quem tem de fazer - desconstruir-se. Por inteiro. Na França, espancaram-na a pauladas, coisa de reis e padres, de tripas e pescoços, faz duzentos anos, e pra quê? Se, agora, está lá, cheio de teólogos/as medievais, de novo. Que não seja outro a converter a teologia - mas ela mesma, "infantilizando-se".

Mas para quê? Para, continuando a terapia morenteana, tornar-se "rigorosa". Não há, tergiversações epistemológicas, Teologia. Fazer-se criança é apenas o primeiro passo, mas, depois, há que se fazer gente grande de novo, e medir, e somar, e pesar, e contar, e enfiar a mão, os pés, e lamber, e cheirar, e ouvir, e tocar. "Os métodos, cumpre dizê-lo dez vezes, são o essencial, e também o mais difícil, e também o que há mais tempo tem contra si os costumes e a preguiça" (NIETZSCHE, 1988, p. 126).

Armamos o laço, tecemos a teia, cavamos o poço - e caímos nele. Enxergaremos onde nos enfiamos? Pois eu sinto o cheiro da maresia, e o metal a corroer, lentamente. MEC - entramos! E umbandistas, também! Logo, não vejo a hora, budistas, kardecistas, quem sabe o candomblé, com judeus e muçulmanos não haveria tanta "novidade", mas vá lá, uns rosas-cruzes, alguns testemunhas de Jeová, uns hare krishnas. Que experiência será perguntar a cada um, quando todos estivermos reunidos, o que é, afinal, teologia. Ah, confesso,

11 Para Morente, o labor filosófico exige, como prévia disposição e ânimo, "admiração" e "rigor". A admiração, diz Morente, é a capacidade de infantilizar-se. A contrapartida é o rigor - no pensamento, na exatidão. Não é fácil, vê-se, ser filósofo. Para sustentar a metáfora psicanalítica, requer que consideremos que é a própria teologia quem deve encontrar-se, perdendo-se. Se a própria teologia deu à luz o século XIX, ouvir aquele século é ouvir-se a si mesma. A teologia está fracionada, alienada de si mesma, porque teme olhar-se no espelho. O diabo de quem ela corre é sua própria sombra. 
vai ser muito divertido. Como assim "estudo de Deus"? Você diz o quê? Os orixás? Como "orixás"? - eles são demônios! Intervenção do MEC. Segunda tentativa. "Estudo dos deuses"? Como assim "dos deuses"? - eles não existem! Mas eu creio. Ah, então é "o estudo da racionalização, dita fé, de certos grupos humanos". Será a pressão do apinhamento de crenças num corredor apertado, numa sala de reuniões, ânimos acirrados, ódios santos recalcados, que arrancaremos da teologia seu atestado de óbito medieval e a traremos para a luz do dia. Sozinha, ela não fará nada. Nunca fez. Lutero fez que ia fazer, mas qual?, No dia seguinte deu de ombros - e tivemos de esperar quinhentos anos para o "livre-exame" ser arrancado à força - e, ainda assim, há quem o amaldiçoe.

Não é que a teologia deva tornar-se atéia. Ela terá de tornar-se cônscia e cética. Passaremos vergonha, por uns dias, remoendo que, no passado medieval de nossas consciências teológicas repetimos e fizemos repetir certas coisas, mas logo o vexame dará lugar a uma sensação de revigoramento e acharemos o lugar da "nova" teologia. A velha só tem lugar no engano de si, no recalque do mundo que inventamos, na encenação do mundo que vem, aqui, onde, então, ela pensa ser alguma coisa. Morreu, coitada, e não sabe. Mas nos arrasta com seu cadáver - aliás, nós o carregamos, procissões intermináveis.

A prova de fogo de sua terapia dar-se-á quando teólogos e teólogas formos para a escola. Não é que a teologia vá, agora, educar o mundo. Pelo contrário - vai sentar-se, comportadamente, e frequentar as aulas. A teologia vai para a escola, e vai jogar o jogo da escola. Vai descobrir quem é, na terapia, e o que é, na escola. Não tenho a mínima idéia de quem - do que - ela sairá, depois desse processo. Mas ele é necessário. Para que surjam novos teólogos de um novo tipo. Crentes, que seja, mas cientes da crença que tem, como mito, eventualmente pessoal, eventualmente comunal - neocrentes, Morin. Recomeçar uma das experiências profundas da espécie sapiens, mas que, em algum momento, abeberou-se da "filosofia", e meteu-se a dizer-se "saber", e acocorouse ao lado do trono, e meteu-se a ser política (ah, cada "igreja" é uma República, disfarçada de Cidade de Deus). Recupero o desejo do Faustino Teixeira de uma teologia livre do poder - e também ela desempoderada! - mas igualmente livre dos "imprescindíveis laços da fé e da revelação". Uma teologia que seja a mesma - ela é método, apenas - para cristãos e hindus, ambos livres das coerções alienantes/manipuladoras da "fé". Desconstruir a teologia, quem sabe e, ainda mais, a religião, para construí-la de novo, evitando aquela trilha que vai dar no "saber" e essa outra aqui, que vai dar na "política". 
Ah, sim, a teologia poderá, sempre, nos alertar para valores para além da medida e do cômputo. Por outro lado, os homens e as mulheres das medidas e dos cômputos hão de, em troca, lembrar à teologia que valores e saberes são - devem ser - construídos aqui e agora, por nós, e que essa mística de fundo da espécie humana - em preservando-se a hipótese - não pode mais ser articulada isoladamente da terra. Mesmo a mística - por um bom tempo, "vigiada" - há de ser compatível.

\section{Considerações finais}

Sou teólogo. Falo como teólogo. Falo para teólogos e teólogas. Não posso, contudo, assumir uma atitude corporativista e engrossar o coro apologético da teologia - defender seu "lugar". Meu sentimento é contraditório. Recebido, pelo MEC, no rol das "ciências", alegro-me, porque minha formação, da noite para o dia, ganha status formal. Mas ressinto-me - talvez, envergonhe-me -, porque reconheço que, em termos materiais, o que a teologia cripto-medieval tem a dizer para as Ciências Humanas não é compatível - e o que ela tem e terá eventualmente a dizer, arrisco afirmar, constitui "saber" construído por meio da instrumentalização de disciplinas das "ciências". O que de propriamente teológico, contudo, resulta incontornavelmente incompatível. Deixar-nos-ão falar, porque ganhamos esse direito - mas, honestamente, quem há de nos querer ouvir? Nem eu mais quero!

A relação conflituosa da teologia com o século XIX precisa de superação urgente. Minha opinião - enquanto teólogo, já o fiz - a teologia "deve" urgentemente "converter-se", "tratar-se", "curar-se". Deve conhecerse e verificar por que tem tanto horror àquele século, justamente aquele em que as bases político-sociais da sociedade contemporânea foram inventadas por nós, sujeitos históricos emancipados, que vivemos nela. Residirá aí, como a dizer, em sua síndrome hierológica, hieropática, hierocrática, sua antipatia?

Coragem, teologia! Ousadia, teólogos! Intrepidez, teólogas! Alea jacta est. O século XXI nos observa. Mas, sem o século XIX, é impossível entrarmos nele. 


\section{Agradecimentos}

Agradeço à Profa. Dra. Mary Rute G. Esperandio pela leitura crítica do ensaio. Irmanalmente preocupada, apontou-me meu "estilo 'impaciente' em relação a algumas 'obviedades' ainda não encaradas pela Teologia e pelos teólogos/as atuais". Mary tem razão - é minha franqueza e fraqueza essa impaciência. As cãs, contudo, me visitam, e, em breve, aprenderei essa política arte de ser paciente.

\section{Referências}

BERGER, Peter. O dossel sagrado: elementos para uma teoria sociológica da religião. 3. ed. São Paulo: Paulus, 1985.

BULTMANN, Rudolf. Novo testamento e mitologia: o problema da desmitologização da proclamação neotestamentária. In: BULTMNN, Rudolf. Crer e compreender. artigos selecionados. São Leopoldo: Sinodal, 1987. p. 51-54.

DILTHEY, Wilhelm. Introduction to the human sciences: selected works of william dilthey. Princeton: Princeton University Press, 1991. v. 1.

DOSSE, François. O império do sentido: a humanização das ciências humanas. Bauru: EDUSC, 2003.

FEUERBACH, Ludwig. A essência do cristianismo. Campinas: Papirus, 1988.

FREUD, Sigmund. O futuro de uma ilusão, o mal estar na civilização e outros trabalhos. Rio de Janeiro: Imago, 2006.

FROMM, Erich. Psychoanalysis and religion. London: Yale University Press, 1971.

GINZBURG, Carlo. Sinais: raízes de um paradigma indiciário. In: GINZBURG, Carlo. Mitos, emblemas, sinais. 2. ed. São Paulo: Cia. das Letras, 2007. 
HUIZINGA, Johan. Homo ludens: o jogo como elemento da cultura. São Paulo: Perspectiva, 2005.

HUXLEY, Aldous. Os demônios de Loudun. São Paulo: Círculo do Livro, 1992.

KANT, Immanuel. Crítica da razão pura. Lisboa: Fundação Calouste Gulbenkian, 2001.

KÜNG, Hans. Freud and the problem of God: Enlarged London: Yale University Press, 1990.

Teologia a caminho: fundamentação para o diálogo ecumênico. São Paulo: Paulinas, 1999.

MARX, Karl. A contribution to the critique of Hegel's philosophy of right. introduction. In: MARX, Karl. Early writings. Introduced by Lucio Colletti. London: Penguin Books, 1992, p. 243-258.

MORENTE, Manuel Garcia. Fundamentos de filosofia: lições preliminares. 8. ed. São Paulo: Mestre JOU, 1980.

MORIN, Edgar. Para sair do século XX. Rio de Janeiro: Nova Fronteira, 1986.

O método 4. As idéias: habitat, vida, costumes, organização. 3. ed. Porto Alegre: Sulinas, 2002.

O método 5. a humanidade da humanidade: a identidade humana. 2. ed. Porto Alegre: Sulinas, 2003.

Os sete saberes necessários à educação do futuro. São Paulo: Cortez, 2004.

MUELLER, Enio Ronald. A teologia e seu estatuto teórico: contribuições para uma discussão atual na universidade brasileira. Revista Estudos Teológicos, São Leopoldo, v. 47, n. 2, p. 88-103, 2007.

NIETZSCHE, Friedrich Wilhelm. Assim falou Zaratustra: um livro para todos e para ninguém. 6. ed. Rio de Janeiro: Bertrand Brasil, 1989.

O Anticristo: ensaio de uma crítica do cristianismo. Lisboa: Guimarães, 1988.

Rev. Pistis Prax., Teol. Pastor., Curitiba, v. 1, n. 1, p. 199-218, jan./jun. 2009 
ONFRAY, Michel. Tratado de ateologia. São Paulo: Martins Fontes, 2007.

PEIRCE, Charles Sanders. Semiótica. São Paulo: Perspectiva, 2003.

PONTIFÍCIA COMISSÃO BÍBLICA. A interpretação da Bíblia na igreja. São Paulo: Paulinas, 2002.

PRIGOGINE, Ilya. O fim das certezas: tempo, caos e as leis da natureza. São Paulo: UNESP, 1996.

PRIGOGINE, Ilya. As leis do caos. São Paulo: UNESP, 2002.

REIS, José Carlos. Dilthey e o historicismo: a redescoberta da história. In: REIS, José Carlos. História e teoria. historicismo, modernidade, temporalidade e verdade. Rio de Janeiro: FGV, 2003, p. 207-246.

RIBEIRO, Osvaldo Luiz. Por uma teologia pós-metafísica: diálogo com um epílogo circunstancial. Correlatio, São Bernardo do Campo, v. 12, 2007. Disponível em: <http://www.metodista.br/ppc/correlatio/correlatio12/por-umateologia-pos-metafisica-2013-dialogo-com-um-epilogo-circunstancial>. Acesso em: 22 nov 2007.

RICOEUR, Paul. Freud and philosophy: an essay on interpretation. London: Yale University Press, 1970.

SARAMAGO, José. O evangelho segundo Jesus Cristo. São Paulo: Cia. das Letras, 1991.

SCHOPENHAUER, Arthur. O mundo como vontade e representação. São Paulo: Publicações Brasil, 1963.

Sobre o fundamento da moral. São Paulo: Martins Fontes, 2001.

TEIXEIRA, Faustino. O lugar da teologia na(s) ciência(s) da religião. In: TEIXEIRA, Faustino. (Org.). A(s) ciência(s) da religião no Brasil: afirmação de uma área acadêmica. São Paulo: Paulinas, 2001. p. 297-346.

TILLICH, Paul. La significación de la historia de las religiones para el teólogo sistemático. In: TILLICH, Paul. EI futuro de las religiones. Buenos Aires: Megápolis, 1977. 
VON SINNER, Rudolf. Teologia como ciência. Revista Estudos Teológicos, São Leopoldo, v. 47, n. 2, p. 57-66, 2007.

ZABATIERO, Júlio Paulo Tavares. Do estatuto acadêmico da teologia: pistas para a solução de um problema complexo. Revista Estudos Teológicos, São Leopoldo, v. 47, n. 2, p. 67-87, 2007.

Recebido: 22/04/2008

Received: 04/22/2008

Aprovado: 15/05/2008 Approved: 05/15/2008 